\title{
FLUKTUASI BAHAN ORGANIK DAN SEBARAN NUTRIEN SERTA KELIMPAHAN FITOPLANKTON DAN KLOROFIL-a DI MUARA SUNGAI SAYUNG DEMAK
}

\author{
Iin Rahmawati, Ign. Boedi Hendrarto, Pujiono W. Purnomo ${ }^{l}$
}

Program Studi Manajemen Sumberdaya Perairan, Jurusan Perikanan

Fakultas Perikanan dan Ilmu Kelautan, Universitas Diponegoro

\begin{abstract}
ABSTRAK
Kegiatan yang terdapat di sekitar muara Sungai Sayung seperti aktivitas manusia, pariwisata, industri rumah tangga, pertambakan, serta jalur pelayaran yang terus berlangsung tanpa pengelolaan yang baik dapat menyebabkan perubahan kondisi fisika, kimia, biologi sehingga akan berpengaruh terhadap kandungan bahan organik, nutrien, dan kelangsungan hidup organisme di dalamnya. Tujuan penelitian ini adalah mengetahui fluktuasi dan sebaran bahan organik di muara Sungai Sayung Demak, mengetahui distribusi spasial sebaran bahan organik dan nutiren terhadap kelimpahan fitoplankton, dan mengetahui keterkaitan antara bahan organik terhadap sebaran nutrien dan distribusi nutrien terhadap klorofil-a.

Penelitian ini berdasarkan studi kasus dan menggunakan metode purposive sampling untuk pengambilan sampel. Dalam penelitian ini ditentukan lima stasiun pengukuran, dimana pada tiap stasiun dilakukan tiga kali pengulangan. Analisis data bahan organik, nutrien, dan klorofil-a menggunakan metode Regresi Korelasi. Bahan organik dengan nitrat secara linier menunjukkan keeratan yang tinggi dengan nilai koefisien korelasi (R) sebesar 0,8209. Hubungan antara bahan organik dengan fosfat mempunyai nilai koefisien korelasi (R) sebesar 0,7804. Distribusi nutrien terhadap klorofil-a menunjukkan adanya gradasi nilai konsentrasi dimana di muara Sungai Sayung lebih tinggi dan akan semakin rendah menuju ke arah laut lepas. Berdasarkan nilai rata - rata klorofil-a yang diperoleh sebesar 1,027 - 1,353 $\mu \mathrm{g} / \mathrm{l}$, perairan muara Sungai Sayung Demak tergolong kedalam perairan yang bersifat Oligotrofik.
\end{abstract}

Kata kunci : Bahan Organik, Nutrien, Klorofil-a, Fitoplankton, Muara Sungai Sayung

\section{ABSTRACT}

The activites around Sayung estuary such as human activity, home industry, tourism activity fishpond, shipping lines, that happend continously without any good management, can cause the chemical, physics, biologics conditions so it will have an effect to the content of organic matter, nutrients, and the survival of aquatic organism. This research purpose were to determine the fluctuation and distribution of organic matter in the estuary of Sayung Demak, the spatial distribution of organic matter and phytoplankton abundance and relation between organic matter and the nutrients as well as nutrient distributions with chlorophyll-a.

This research based on case study and using the sampling purposive method for taking samples. This research used five stations with three replication in each station. Analysis data of organic matter, nutrients, chlorophyll-a used the Regression Corellation method. Organic matter was highly correlated with nitrate ( $\mathrm{R}=$ $0,8209)$, as well as between organic matter with phosphate concentrations $(\mathrm{R}=0,7804)$. The distribution of nutrients against chlorophyll-a indicating gradation existence of concentration value where the Sayung's estuary has highest values and it was lower towards seashores. Based on the value of chlorophyll-a concentration that was $1,027-1,353 \mu \mathrm{g} / \mathrm{l}$, Sayung waters was classesified into Olygothrophycs.

Keywords: Organic Matter, Nutrient, Phytoplankton, Chlorophyll-a, Sayung Estuaries

\section{Pendahuluan}

Perairan Muara Sungai Sayung Demak berada di daerah pantai utara Jawa mempunyai karakteristik landai, tidak terlalu dalam dengan beragam populasi jenis biota yang ada. Kondisi suatu wilayah pesisir erat kaitannya dengan sungai yang bermuara di wilayah itu. Suatu ekosistem wilayah pesisir dapat terbentuk oleh adanya interaksi antara makhluk hidup dengan makhluk hidup lainnya dan antara makhluk hidup dengan lingkungan abiotik (habitat). Interaksi dalam ekosistem didasari adanya hubungan saling membutuhkan antara sesama makhluk hidup. Keberlangsungan tersebut membuat setiap individu berjuang untuk dapat mempertahankan hidupnya sehingga mampu memproduksi segala hal yang dibutuhkan dalam melangsungkan kehidupannya. Oleh karena itu, wilayah pesisir secara alami merupakan bagian yang tak terpisahkan dari suatu sistem aliran sungai.

Ekosistem estuari di kawasan muara Sungai Sayung Demak dikelilingi oleh pohon mangrove. Ekosistem perairan estuari merupakan perairan yang sangat subur karena menjadi tempat penampung zat hara (nutrien) yang terbawa oleh sungai dari daratan. Dari proses dinamika di estuari, kandungan nutrien itu

*) Penulis Penanggung Jawab 
akan mengalami pengenceran dan penyebaran dengan bantuan arus dan pasang surut. Parameter kualitas air dari suatu sumber air permukaan pada perairan estuari dapat dilihat atau diamati dari arus, pasang surut, kandungan oksigen terlarutnya (DO), salinitas, $\mathrm{pH}$ (derajat keasaman), kebutuhan akan biologi (fitoplankton dan klorofil-a). Berdasarkan parameter tersebut, kualitas air yang baik adalah air yang mengandung cukup oksigen yang sebagian besar digunakan untuk kelangsungan hidup biota di perairan tersebut. Pada kenyataanya, terdapat beberapa faktor yang sangat mempengaruhi keseimbangan kandungan oksigen dalam air antara lain kehadiran unsur nutrien dalam air (Muller - Wohlfeil et al., 2002). Perairan estuari dicirikan adanya fluktuasi bahan organik dari aktivitas luar. Bahan organik yang terlalu besar berpotensi dapat menurunkan kualitas lingkungan perairan. Bahan organik selanjutnya bersama dengan parameter kimia dan fisika khususnya seperti pasang surut, arus, pengadukan akan masuk ke dalam ekosistem laut. Percampuran baik air tawar dan air laut yang membawa bahan organik apabila keduanya bertemu dan tingkat percampurannya tergantung pada faktor lingkungan pada satu sisi akan dapat memasok nutrien penting yang mendukung produktivitas perairan. Hal - hal sesuai dengan pendapat Nybakken (1992) menyatakan bahwa perairan pantai termasuk estuari menerima sejumlah besar unsur - unsur penting, yaitu nitrat dan fosfat melalui aliran dari daratan.

Tujuan dari penelitian ini yaitu untuk mengetahui fluktuasi dan sebaran bahan organik di muara Sungai Sayung Demak; mengetahui distribusi spasial sebaran bahan organik dan nutiren terhadap kelimpahan fitoplankton muara Sungai Sayung Demak; dan mengetahui keterkaitan antara bahan organik terhadap sebaran nutrien dan distribusi nutrien terhadap klorofil-a serta tingkat kesuburan perairan berdasarkan kandungan klorofil-a fitoplankton di muara Sungai Sayung Demak. Penelitian ini dilaksanakan pada bulan April - Mei 2013 di sekitar perairan muara Sungai Sayung, Demak, Semarang. Hasil penelitian ini diharapkan dapat menjadi sumber informasi yang bermanfaat bagi pengelolaan dan pengembangan sumber daya pesisir dan laut khususnya kawasan perairan Muara Sungai Sayung Demak dalam meningkatkan pemanfaatan sumber daya pesisir dan laut serta sumber daya perikanan.

\section{Materi dan Metode Penelitian}

\section{A. Materi Penelitian}

Materi yang digunakan dalam penelitian ini adalah Materi yang digunakan dalam penelitian ini di muara Sungai Sayung Demak terdiri dari variabel utama dan variabel pendukung. Variabel utama terdiri dari jenis - jenis fitoplankton, klorofil-a, bahan organik, nitrat, dan fosfat dan variabel penunjang (variabel fisika dan variabel kimia). Alat-alat yang digunakan dalam penelitian ini adalah refrakrometer untuk mengukur salinitas, termometer air raksa untuk mengukur suhu, seschi disc untuk mengukur kecerahan dan kedalaman, $\mathrm{pH}$ paper untuk mengukur $\mathrm{pH}$, botol aqua untuk mengambil sampel air, plankton net dengan ukuran 25 mikron untuk menjaring fitoplankton, pipet tetes untuk mengambil formalin, GPS untuk mengetahui koordinat titik sampling, kamera digital untuk dokumentasi, stopwatch sebagai waktu untuk mengukur arus, plastik hitam untuk membungkus botol sampel klorofil-a, ember, es batu, stereofoam sebagai tempat untuk menyimpan sampel dan menjaga keamanan sampel, kertas label untuk memberi tanda pada sampel, alat tulis untuk mencatat data hasil pengamatan, tabung pereaksi sebagai tempat klorofil-a, aluminium foil untuk membungkus tabung pereaksi, mikroskop sebagai alat bantu untuk melihat jenis fitoplankton, sedgwickrafter untuk mencacah fitoplankton, buku identifikasi plankton, aseton untuk melarutkan sampel klorofil-a, spektofotometer untuk mengetahui nilai kandungan klorofil-a.

\section{B. Metode Penelitian}

Metode yang digunakan dalam penelitian ini adalah studi kasus. Metode ini merupakan suatu metode yang mempelajari objek secara mendalam pada waktu, tempat, dan populasi yang terbatas sehingga informasi yang diperoleh hanya bersifat lokal dan hasilnya tidak berlaku untuk tempat dan waktu yang berbeda (Hermawan, 2007). Dalam penentuan lokasi penelitian dan teknik pengambilan sampel menggunakan metode "Purposive Sampling" sehingga didapatkan gambaran lokasi penelitian secara keseluruhan. Dengan demikian, lokasi yang dimaksud harus mewakili ekosistem di muara Sungai Sayung Demak tersebut.

\section{Penentuan titik sampling}

Lokasi pengambilan sampel dilakukan dengan menentukan 5 (lima) stasiun pengukuran. Penentuan titik sampling didasarkan menggunakan rumus "Dispersion in Rivers" yang mana diketahui sebagai berikut:

$$
E_{y}=\varnothing d u^{*}(\text { Czernuszenko, 1987) }
$$

Keterangan:

$$
\begin{aligned}
& E y=\text { wilayah ketergantungan dispersi polutan }\left(\mathrm{m}^{2} / \mathrm{det}\right) \\
& \varnothing=0,23 \text { (Yotsukura and Sayre, } 1976) \\
& d=\text { kedalaman }(\mathrm{m}) \\
& u^{*}=\operatorname{velocity~}(\mathrm{m} / \mathrm{s})
\end{aligned}
$$


Berdasarkan rumus diatas maka dapat dilakukan perhitungan untuk menentukan jarak antar stasiun lokasi penelitian yaitu dengan cara menghitung terlebih dahulu jarak antar stasiun dengan aljabar logaritma yang akan didapatkan hasil sin cos tan pada tiap sisi yang kemudian dimasukkan dalam rumus diatas sehingga ditemukan hasil jarak antar tiap stasiun lokasi penelitian yaitu berjarak $50 \mathrm{~m}$. Stasiun pengambilan sampel dilakukan pada muara sungai. Pembagian lokasi pengambilan sampel terdiri dari 5 (lima) stasiun. Pengulangan dalam pengambilan sampel dilakukan sebanyak 3 (tiga) kali yang dilakukan secara sistematik satu minggu sekali dengan jarak interval satu minggu selama sebulan.

\section{Teknik Pengambilan Sampel}

Pengambilan sampel air dilakukan dengan menggunakan ember $25 \mathrm{ml}$ sebanyak 4 (empat) kali untuk sampel fitoplankton. Pengambilan sampel air untuk pengukuran parameter - parameter fisika-kimia perairan dilakukan di lapisan pertengahan. Sampel air yang diambil dari masing-masing stasiun kemudian dimasukkan ke dalam botol sampel untuk melakukan analisa kimia (bahan organik, klorofil-a, nitrat, dan fosfat). Pengambilan sampel air dengan pengulangan pada masing-masing stasiun sebanyak 3 (tiga) kali selama sebulan. Pengambilan sampel air diupayakan tidak terjadi goncangan pada permukaan air, dengan tujuan agar tidak terjadi percampuran air permukaan dengan air di kedalaman.

\section{Hasil dan Pembahasan \\ Deskripsi lokasi}

Pengambilan sampel pada penelitian ini mengambil lokasi di muara Sungai Sayung Demak. Muara sungai tersebut merupakan salah satu perairan yang berasal dari daerah aliran Sungai Sayung, Kecamatan Sayung, Kabupaten Demak, Provinsi Jawa Tengah. Muara sungai ini memiliki lebar sungai sekitar 40 meter, kedalaman $100 \mathrm{~cm}$ dengan debit aliran sungai yang berfluktuasi tergantung pasang surut dan curah hujan. Muara Sungai Sayung Demak di dominasi oleh pemukiman, pertambakan, pertanian, dan industri rumah tangga. Mata pencaharian sebagian besar penduduk bekerja sebagai nelayan dan petani. Selain itu bekerja sebagai buruh tani, buruh swasta, pedagang, dan perangkat desa.

Secara geografis muara Sungai Sayung Demak stasiun 1 terletak pada $06^{\circ} 55^{\prime}$ - 24.6' LS dan $110^{\circ} 28^{\prime}$ - 38.6" BT merupakan lokasi pengambilan sampel yang lebih dekat ke arah tawar, stasiun 2 terletak pada $06^{\circ} 55^{\prime}$ - 21.0' LS dan $110^{\circ} 28^{\prime}-35.9^{\prime \prime}$ BT merupakan titik pengambilan sampel pada bagian pinggir dari muara sungai, stasiun 3 terletak pada $06^{\circ} 55^{\prime}$ - 25.0' LS dan 110 $28^{\prime}$ - 33.6' BT merupakan bagian tengah muara sungai, stasiun 4 terletak pada $06^{\circ} 55^{\prime}$ - 27.9' LS dan $110^{\circ} 28^{\prime}$ - 36.6" BT merupakan titik pengambilan sampel pada bagian kiri dari muara sungai, dan stasiun 5 terletak pada $06^{\circ} 55^{\prime}-25.1$ ' ' BT dan $110^{\circ} 28^{\prime}-37.8^{\prime \prime}$ BT merupakan titik pengambilan sampel yang berada di laut.

\section{Variabel Utama}

Hasil pengamatan kelimpahan fitoplankton, klorofil-a dan parameter kimia disajikan pada Tabel 1.

Tabel 1. Hasil pengamatan variabel utama di muara Sungai Sayung Demak

\begin{tabular}{|c|c|c|c|c|c|c|c|}
\hline \multirow{2}{*}{ Waktu } & \multirow{2}{*}{ Stasiun } & \multirow{2}{*}{$\begin{array}{c}\mathrm{BO} \\
(\mathrm{mg} / \mathrm{l})\end{array}$} & \multirow{2}{*}{$\begin{array}{c}\mathrm{NO}_{3} \\
(\mathrm{mg} / \mathrm{l}) \\
\end{array}$} & \multirow{2}{*}{$\begin{array}{c}\mathrm{PO}_{4} \\
(\mathrm{mg} / \mathrm{l}) \\
\end{array}$} & \multicolumn{2}{|c|}{ Fitoplankton } & \multirow{2}{*}{$\begin{array}{c}\text { Klorofil-a } \\
(\mu \mathrm{g} / \mathrm{l})\end{array}$} \\
\hline & & & & & $\mathrm{ind} / \mathrm{L}$ & Spesies & \\
\hline \multirow[t]{5}{*}{ I } & 1 & 614 & 1,23 & 0,52 & 5391 & 19 & 1,252 \\
\hline & 2 & 576 & 0,7 & 0,62 & 6112 & 20 & 1,268 \\
\hline & 3 & 714 & 2,3 & 1,59 & 5053 & 18 & 1,351 \\
\hline & 4 & 482 & 0,77 & 0,81 & 4667 & 19 & 1,152 \\
\hline & 5 & 395 & 0,42 & 0,37 & 3736 & 15 & 1,135 \\
\hline \multirow[t]{5}{*}{ II } & 1 & 476 & 0,55 & 0,37 & 5477 & 17 & 1,061 \\
\hline & 2 & 734 & 2,25 & 1,73 & 4160 & 16 & 1,206 \\
\hline & 3 & 382 & 0,44 & 0,36 & 4371 & 18 & 1,027 \\
\hline & 4 & 600 & 1,25 & 0,56 & 3822 & 18 & 1,128 \\
\hline & 5 & 525 & 1,2 & 0,46 & 6408 & 18 & 1,118 \\
\hline \multirow[t]{5}{*}{ III } & 1 & 734 & 2,34 & 1,31 & 6370 & 20 & 1,353 \\
\hline & 2 & 500 & 1,8 & 0,57 & 3778 & 20 & 1,142 \\
\hline & 3 & 482 & 1,69 & 0,54 & 5433 & 16 & 1,263 \\
\hline & 4 & 234 & 0,43 & 0,37 & 4583 & 18 & 1,251 \\
\hline & 5 & 314 & 0,5 & 0,46 & 4457 & 16 & 1,161 \\
\hline
\end{tabular}




\section{Distribusi Spasial Kandungan Bahan Organik Air}

Berdasarkan hasil analisis laboratorium didapatkan nilai kandungan bahan organik air berkisar antara 234 - $734 \mathrm{mg} / \mathrm{L}$. Nilai kandungan bahan organik air tertinggi minggu pertama terdapat pada stasiun 3, sedangkan nilai kandungan bahan organik air terendah terdapat pada stasiun 5. Pada minggu kedua nilai kandungan bahan organik air tertinggi terdapat pada stasiun 2, sedangkan nilai kandungan bahan organik air terendah terdapat pada stasiun 3. Pada minggu terakhir (ketiga) nilai kandungan bahan organik air tertinggi terdapat pada stasiun 1, sedangkan nilai kandungan bahan organik air terendah terdapat pada stasiun 4 . Berikut ini adalah gambaran hasil analisis penyebaran nilai kandungan bahan organik air di muara Sungai Sayung Demak.
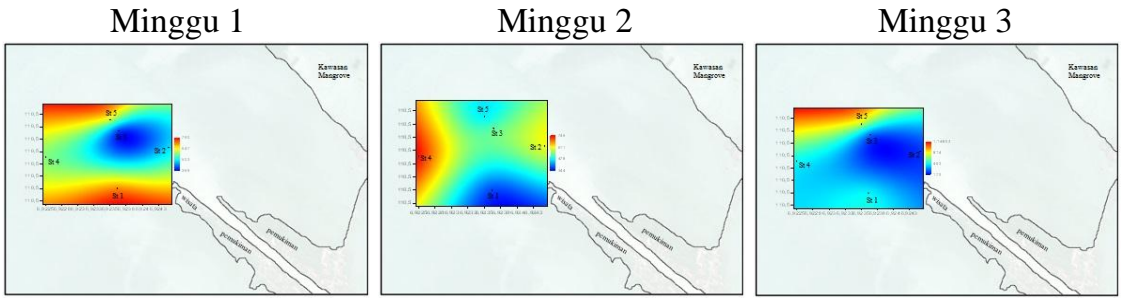

Gambar 1. Penyebaran nilai kandungan bahan organik air

Pada ketiga gambar di atas yang menunjukkan bahwa nilai kandungan bahan organik air cenderung mempunyai pola penyebaran yang sama. Berdasarkan pengolahan data yang dilakukan dengan bantuan software PAST dapat diketahui bahwa pola penyebaran (distribusi) dari bahan organik yang ditemukan di tiap-tiap stasiun penelitian di perairan muara Sungai Sayung Demak adalah termasuk distribusi merata, dimana penyebarannya lebih teratur.

\section{Distribusi Spasial Kandungan Nitrat $\left(\mathrm{NO}_{3}\right)$}

Berdasarkan hasil analisis laboratorium didapatkan nilai kandungan nitrat $\left(\mathrm{NO}_{3}\right)$ berkisar antara $0,42-$ 2,34 mg/L. Menurut Boney (1975), Kisaran pengukuran nitrat tergolong optimum yaitu berkisar >0,36 $\mathrm{mg} / \mathrm{L}$. Nilai kandungan nitrat tertinggi minggu pertama terdapat pada stasiun 3, sedangkan nilai kandungan nitrat terendah terdapat pada stasiun 5. Nilai kandungan nitrat tertinggi minggu kedua terdapat pada stasiun 2, sedangkan nilai kandungan nitrat terendah terdapat pada stasiun 3. Nilai kandungan nitrat tertinggi minggu ketiga terdapat pada stasiun 1, sedangkan nilai kandungan nitrat yang terendah terdapat pada stasiun 4 . Berdasarkan fenomena tersebut, maka nampak bahwa sebaran nitrat selalu mensuplai perubahan secara spasial dan temporal. Pola sebaran perubahan tersebut dapat ditunjukkan pada gambar berikut:

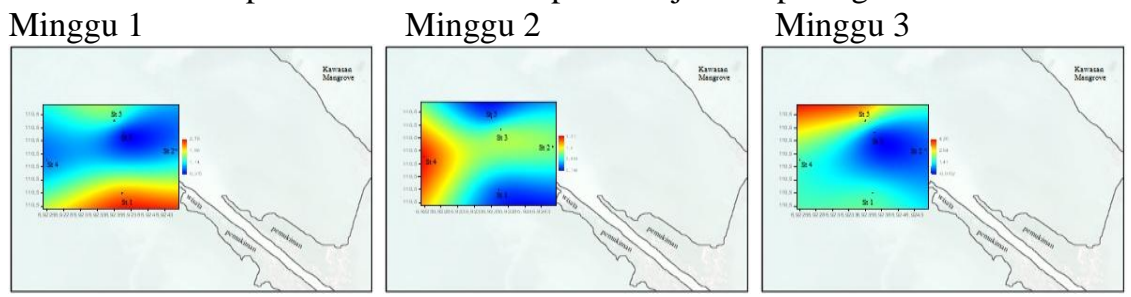

Gambar 2. Penyebaran nilai kandungan nitrat $\left(\mathrm{NO}_{3}\right)$

Distribusi spasial kandungan nitrat pola penyebarannya relatif mempunyai kemiripan yang sama pada tiap pengulangannya. Dua peubah utama kajian adalah hubungan nitrat $\left(\mathrm{NO}_{3}\right)$ dan bahan organik. Grafik hubungan antara nitrat dan bahan organik adalah sebagai berikut:

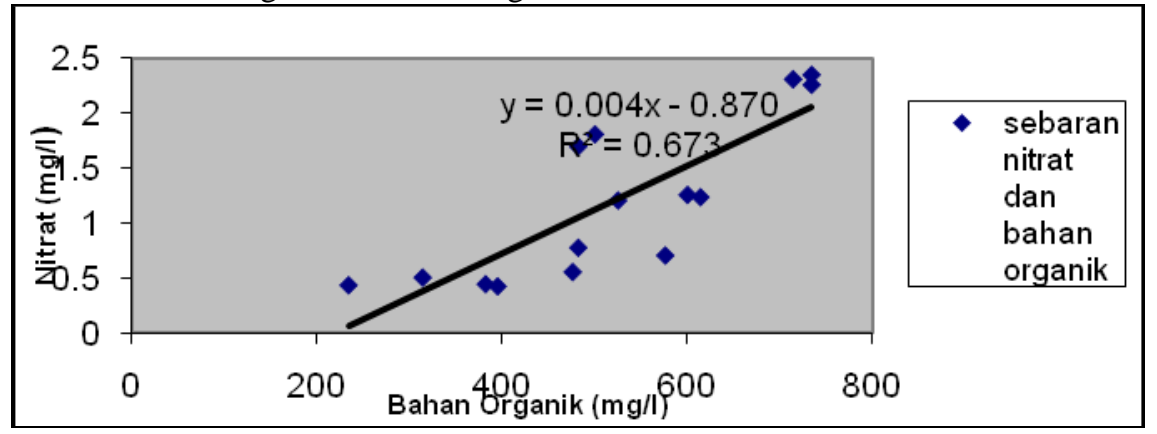

Gambar 3. Grafik Hubungan antara Nitrat $\left(\mathrm{NO}_{3}\right)$ dan Bahan Organik

\section{Distribusi Spasial Kandungan Fosfat $\left(\mathrm{PO}_{4}\right)$}

Berdasarkan hasil analisis laboratorium didapatkan nilai kandungan phosphat $\left(\mathrm{PO}_{4}\right)$ berkisar antara 0,37 - 1,73 mg/L. Menurut Wardoyo (1975), Kisaran pengukuran fosfat tergolong sangat baik yaitu berkisar 
antara 0,101 - 0,200 mg/L. Gambaran hasil analisis nilai kandungan fosfat di muara Sungai Sayung Demak, sebaran fosfat selalu mensuplai perubahan secara spasial dan temporal. Pola sebaran perubahan tersebut dapat ditunjukkan pada gambar berikut:
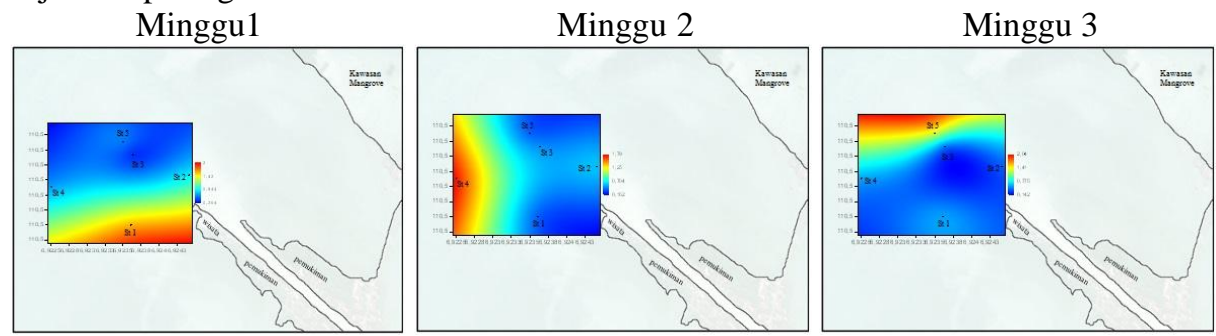

Gambar 4. Penyebaran nilai kandungan phosphat $\left(\mathrm{PO}_{4}\right)$

Distribusi spasial kandungan fosfat pola penyebarannya relatif mempunyai kemiripan yang sama pada tiap pengulangannya. Dua peubah utama kajian adalah hubungan fosfat $\left(\mathrm{PO}_{4}\right)$ dan bahan organik. Grafik hubungan antara fosfat dan bahan organik adalah sebagai berikut:

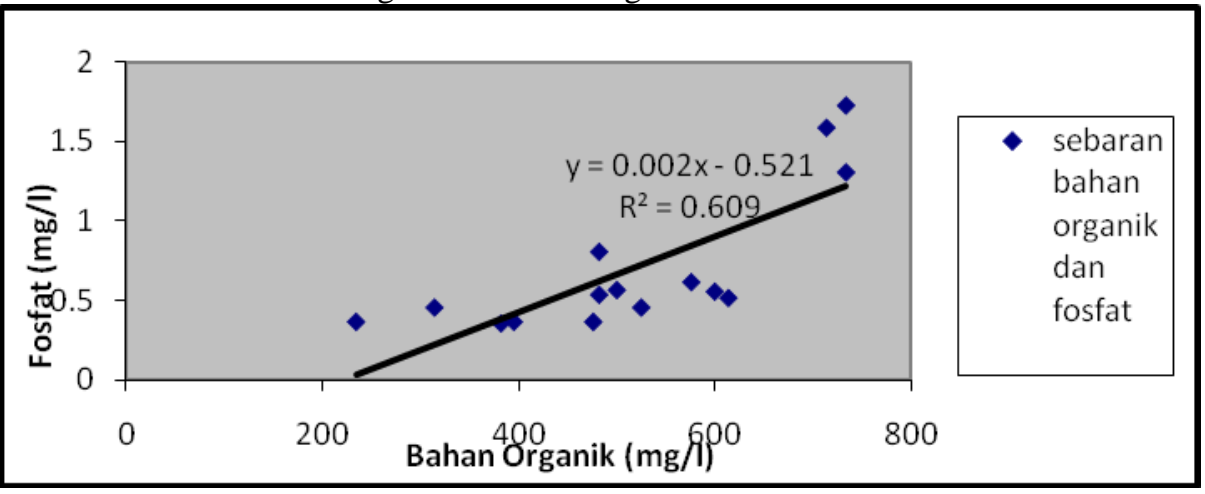

Gambar 5. Grafik Hubungan antara Fosfat $\left(\mathrm{PO}_{4}\right)$ dan Bahan Organik

\section{Distribusi Spasial Struktur Komunitas Fitoplankton}

Fitoplankton yang didapatkan dari hasil sampling penelitian sebanyak 20 genera yang terdiri dari 4 (empat) kelas yaitu Cyanophyceae, Chlorophyceae, Bacillariophyceae, dan Pyrophyta. Dalam kelas Cyanophyceae terdapat 7 genera, kelas Chlorophyceae terdapat 6 genera, kelas Bacillariophyceae terdapat 5 genera, dan kelas Pyrophyta terdapat 2 genera. Nilai kelimpahan fitoplankton berkisar antara $3736-6408$ ind/L. Genera yang paling sering ditemukan dan sekaligus mempunyai kelimpahan tertinggi pada setiap lokasi adalah Spirulina sp, Anabaenopsis sp, Microcystis sp, Chrooccocus sp, Nitszschia sp, Chaetoceros sp, Bacteriastrum sp, Coscinodiscus sp, Ceratium sp. Hasil perhitungan yang diperoleh dari nilai indeks keanekaragaman $\left(\mathrm{H}^{\prime}\right)$ berkisar antara 1,971 - 2,751; indeks keseragaman (e) berkisar antara 0,710 - 0,918; dan indeks dominasi (D) berkisar antara 0,18-0,214. Berikut ini adalah gambaran pola sebaran kelimpahan fitoplankton di muara Sungai Sayung Demak yang disajikan pada gambar berikut:

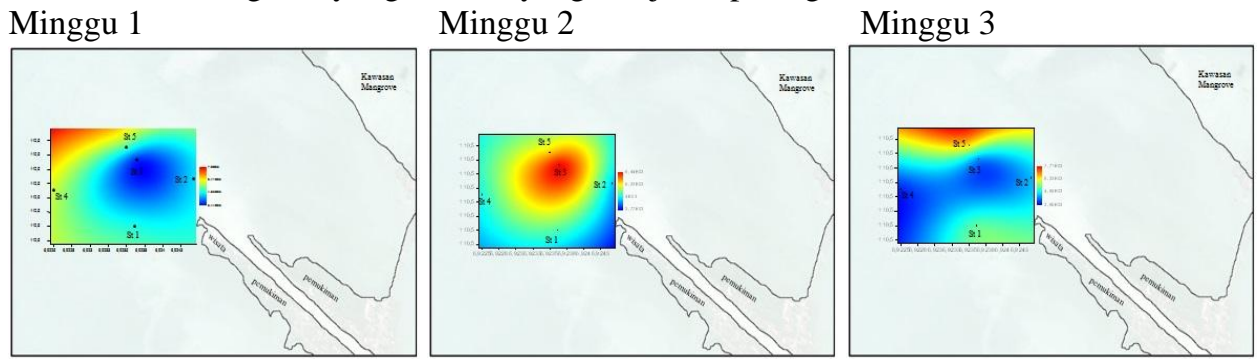

Gambar 6. Pola sebaran kelimpahan fitoplankton

Distribusi spasial kandungan kelimpahan fitoplankton pola penyebarannya relatif mempunyai kemiripan yang sama pada tiap pengulangannya.

\section{Distribusi Spasial Kandungan Klorofil-a Fitoplankton}

Hasil perhitungan klorofil-a selama penelitian maka didapatkan hasil penelitian kandungan klorofil-a berkisar antara 1,027 - 1,353 $\mu \mathrm{g} / \mathrm{l}$. Dua peubah utama kajian adalah hubungan klorofil-a dan nitrat $\left(\mathrm{NO}_{3}\right)$; klorofil-a dan phosphat $\left(\mathrm{PO}_{4}\right)$. Berikut ini adalah gambaran pola sebaran kandungan klorofil-a fitoplankton di muara Sungai Sayung Demak tersaji pada gambar berikut: 

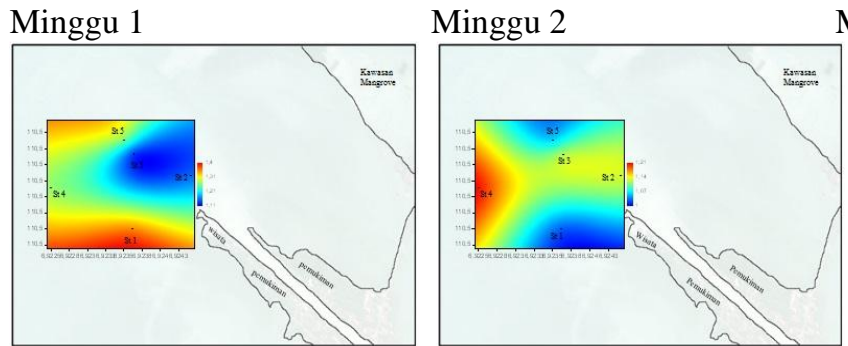

Minggu 3

Gambar 7. Pola sebaran Kandungan Klorofil-a Fitoplankton

Distribusi spasial kandungan klorofil-a pola penyebarannya relatif mempunyai kemiripan yang sama pada tiap pengulangannya. Grafik hubungan antara nitrat, fosfat dan klorofil-a tersaji pada gambar berikut:

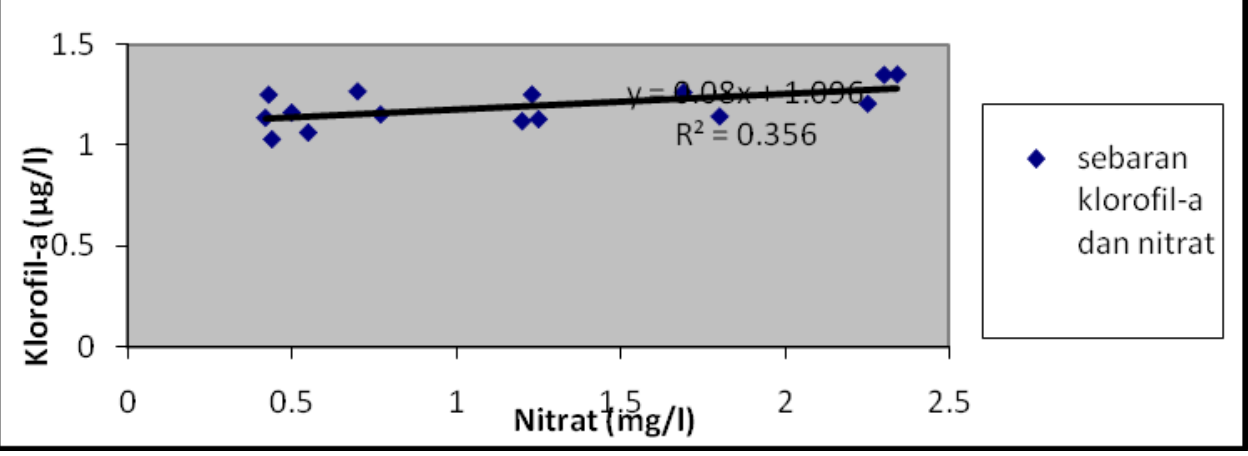

Gambar 8. Grafik Regresi Hubungan Antara Klorofil-a dan Nitrat $\left(\mathrm{NO}_{3}\right)$ di muara Sungai Sayung

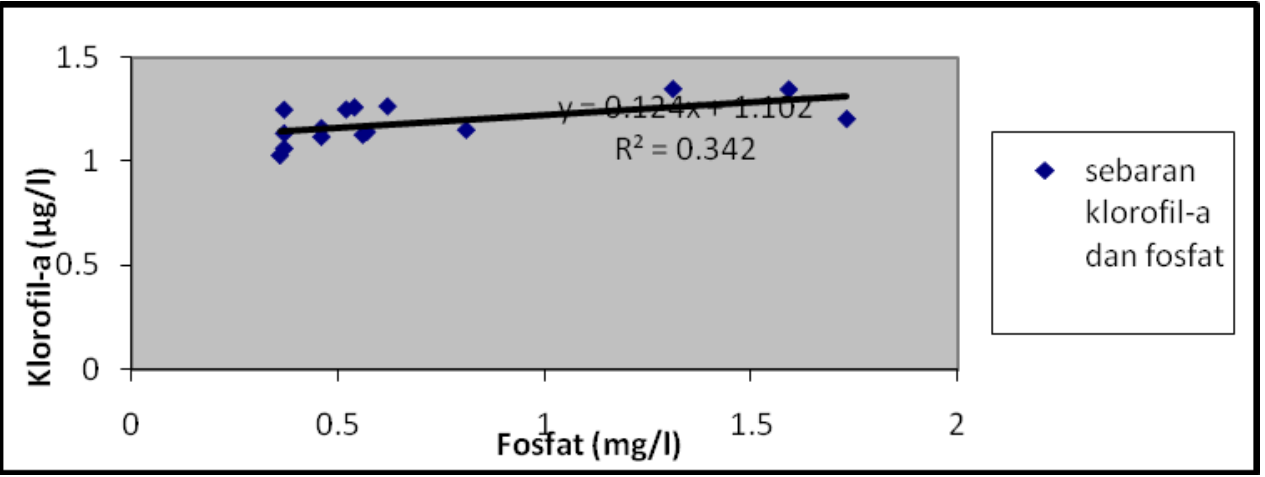

Gambar 9. Grafik Regresi Hubungan Antara Klorofil-a Phosphat $\left(\mathrm{PO}_{4}\right)$ dan di muara Sungai Sayung

\section{Regresi Korelasi Bahan Organik Dengan Nitrat}

Sebelum melakukan analisis regresi, terlebih dahulu melakukan analisis korelasi untuk meyakinkan bahwa apakah terdapat korelasi antara kandungan bahan organik (X) terhadap nitrat (Y). Kisaran dari koefisien korelasi ( $\mathrm{r}$ ) adalah tidak lebih dari $-1 \leq \mathrm{r} \leq+1$, apabila nilai $\mathrm{r}=-1$ artinya korelasinya negatif; $\mathrm{r}=$ 0 artinya tidak ada korelasi; dan $r=1$ artinya korelasinya positif atau sangat kuat. Untuk mengetahui keeratan hubungan digunakan koefisien korelasi (r) dimana nilai r berada antara 0 - 1. Menurut Razak (1991) dalam Ibnu, keeratan nilainya yaitu berkisar antara 0,00-0,20 (hubungan sangat lemah); 0,21 - 0,40 (hubungan lemah); 0,41 - 0,70 (hubungan sedang); 0,71 - 0,90 (hubungan kuat); 0,91-1,00 (hubungan sangat kuat).

Hasil dari perhitungan diperoleh nilai koefisien korelasi $\mathrm{r}=0,8209$ sehingga dapat dikatakan bahwa hubungan kandungan bahan organik dengan nitrat kuat. Nilai koefisien determinan koefisien penentu (KP) sebesar 67,39\% artinya besar pengaruh kandungan bahan organik terhadap nitrat sebesar 67,39\% dan sisanya 32,61\% dipengaruhi oleh faktor lain. Hasil dari analisis regresi diperoleh nilai b sebesar 0,00398 dan nilai a sebesar $-0,8703$ sehingga bentuk persamaan regresi $\mathrm{Y}=0,0039 \mathrm{x}-0,870$ (Gambar 1). Berdasarkan hasil analisa regresi didapatkan nilai $F_{\text {hitung }}$ pada selang kepercayaan 0,05 sebesar 26,86 sedangkan nilai $F_{\text {tabel }}$ pada selang kepercayaan sebesar 0,05 adalah 4,67 atau 26,86>4,67, ini menunjukan bahwa menerima $\mathrm{H}_{1}$ dan menolak $\mathrm{H}_{0}$ yang artinya terdapat pengaruh antara nilai kandungan bahan organik terhadap nilai kandungan nitrat di muara Sungai Sayung Demak. 


\section{Regresi Korelasi Bahan Organik Dengan Fosfat}

Dari hasil analisis statistik yang telah dilakukan didapatka nilai koefisien korelasi (r) sebesar 0,7804 dan nilai koefisien determinasi sebesar $60,90 \%$. Dengan nilai tersebut dapat dikatakan bahwa terdapat hubungan kuat antara kandungan bahan organik dengan fosfat dan pengaruh kandungan bahan organik terhadap fosfat sebesar $60,90 \%$ dan sisanya $31,9 \%$ dipengaruhi oleh faktor yang lain. Hasil dari analisis regresi diperoleh nilai $\mathrm{b}$ sebesar 0,00237 dan nilai a sebesar $-0,5113$ sehingga bentuk persamaan regresi $\mathrm{Y}=$ $0,0024 \mathrm{x}$ - 0,5213 (Gambar 2). Berdasarkan hasil analisa regresi didapatkan nilai $\mathrm{F}_{\text {hitung pada selang }}$ kepercayaan 0,05 sebesar 20,25 sedangkan nilai $F_{\text {tabel }}$ pada selang kepercayaan sebesar 0,05 adalah 4,67 atau $20,25>4,67$, ini menunjukan bahwa menerima $\mathrm{H}_{1}$ dan menolak $\mathrm{H}_{0}$ yang artinya terdapat pengaruh antara kandungan bahan organik terhadap kandungan fosfat di muara Sungai Sayung Demak. Kesimpulan dari uraian tersebut terdapat hubungan antara kandungan bahan organik terhadap kandungan fosfat adalah signifikan.

\section{Regresi Korelasi Klorofil-a Dengan Nitrat}

Hasil dari perhitungan diperoleh nilai koefisien korelasi $r=0,598$ sehingga dapat dikatakan bahwa hubungan kandungan klorofil-a dengan nitrat terdapat hubungan sedang. Nilai koefisien penentu (KP) sebesar 35,76\% artinya besar pengaruh kandungan klorofil-a terhadap nitrat sebesar 35,76\% dan sisanya $64,24 \%$ dipengaruhi oleh faktor lain. Hasil dari analisis regresi diperoleh nilai b sebesar 0,08 dan nilai a sebesar 1,096 sehingga bentuk persamaan regresi $\mathrm{Y}=0,08 \mathrm{x}+1,096$ (Gambar 3). Berdasarkan hasil analisa regresi didapatkan nilai $F_{\text {hitung }}$ pada selang kepercayaan 0,05 sebesar 7,20 sedangkan nilai $F_{\text {tabel }}$ pada selang kepercayaan sebesar 0,05 adalah 4,67 atau 7,20>4,67, ini menunjukan bahwa menerima $\mathrm{H}_{1}$ dan menolak $\mathrm{H}_{0}$ yang artinya terdapat pengaruh antara kandungan klorofil-a terhadap kandungan nitrat di muara Sungai Sayung Demak. Perhitungan yang didapat adalah hubungan kandungan klorofil-a terhadap nitrat adalah signifikan.

\section{Regresi Korelasi Klorofil-a Dengan Fosfat}

Hasil dari perhitungan diperoleh nilai koefisien korelasi $r=0,5848$ sehingga dapat dikatakan bahwa hubungan kandungan klorofil-a dengan fosfat terdapat hubungan sedang. Nilai koefisien penentu (KP) sebesar 34,20\% artinya besar pengaruh kandungan klorofil-a terhadap fosfat sebesar 34,20\% dan sisanya $65,8 \%$ dipengaruhi oleh faktor lain. Hasil dari analisis regresi diperoleh nilai b sebesar 0,124 dan nilai a sebesar 1,102 sehingga bentuk persamaan regresi $\mathrm{Y}=0,124 \mathrm{x}+1,102$ (Gambar 4). Berdasarkan hasil analisa regresi didapatkan nilai $F_{\text {hitung }}$ pada selang kepercayaan 0,05 sebesar 6,76 sedangkan nilai $F_{\text {tabel }}$ pada selang kepercayaan sebesar 0,05 adalah 4,67 atau 6,76>4,67, ini menunjukan bahwa menerima $\mathrm{H}_{1}$ dan menolak $\mathrm{H}_{0}$ yang artinya terdapat pengaruh antara kandungan klorofil-a terhadap kandungan fosfat di muara Sungai Sayung Demak. Kesimpulan dari hasil perhitungan yang didapat adalah hubungan kandungan klorofil-a terhadap fosfat adalah signifikan.

\section{Pembahasan \\ Komunitas Fitoplankton}

Dari data hasil penelitian yang diperoleh dari sampling kelima stasiun diketahui bahwa genera yang mendominasi di perairan muara Sungai Sayung tersebut yaitu berasal dari kelas Cyanophyceae dan Bacillariophyceae. Menurut Nybakken (1992), kelas dari Bacillariophyceae mampu tumbuh dengan cepat meskipun pada kondisi cahaya dan nutrien yang rendah. Hal tersebut juga dikarenakan jenis fitoplankton ini mempunyai kemampuan beradaptasi dengan baik sehingga mampu meregenarasi dan bereproduksi dalam jumlah yang lebih besar dari jenis fitoplankton yang lain. Jenis dari plankton tersebut juga merupakan jenis yang paling tahan terhadap perubahan lingkungan oleh pengaruh pasang surut. Kelimpahan fitoplankton pada suatu perairan selalu berkaitan erat dengan kondisi di sekitar lingkungan perairan tersebut. Pada gambar grafik kelimpahan fitoplankton terlihat bahwa kelimpahan individu tertinggi pada minggu pertama terdapat pada stasiun II, sedangkan kelimpahan individu terendah pada stasiun V. Minggu kedua kelimpahan individu tertinggi pada stasiun $\mathrm{V}$ dan kelimpahan individu terendah pada stasiun IV. Minggu terakhir kelimpahan individu tertinggi terdapat pada stasiun I, sedangkan kelimpahan individu terendah terdapat pada stasiun II. Pada stasiun I dan II memiliki kelimpahan individu fitoplankton yang baik karena pada kedua stasiun tersebut merupakan lokasi yang terletak pada pertengahan dari muara Sungai Sayung yang langsung berbatasan langsung dengan laut. Kelimpahan tersebut diduga berkaitan dengan unsur - unsur nutrien yaitu tingginya kandungan nitrat dan fosfat yang terdapat pada lokasi tersebut. Hal tersebut sesuai dengan pendapat Nybakken (1992) dalam Muchtar Muswerry (2012) bahwa fitoplankton merupakan salah satu parameter biologi yang erat hubungannya dengan kedua zat hara (nitrat dan fosfat), yang merupakan zat - zat yang diperlukan dan mempunyai pengaruh besar terhadap proses pertumbuhan dan perkembangan hidupnya.

Nilai indeks keseragaman (e) fitoplankton di muara Sungai Sayung Demak yaitu berkisar antara 0,710 - 0,918. Nilai tersebut cukup tinggi dan menandakan bahwa nilai keseragaman individu plankton antar 
spesies relatif menyebar secara merata dengan nilai 0 - 1 (Odum, 2005). Hal ini disebabkan karena tidak terdapat spesies yang mendominasi spesies lainnya yang diperlihatkan oleh nilai indeks dominansi yang mendekati nilai 0 - 1. Nilai keseragaman (e) apabila mendekati nol berarti keseragaman antar spesies di dalam komunitas tergolong rendah dan sebaliknya keseragaman yang mendekati satu dikatakan keseragaman antar spesies tergolong merata atau sama (Pirzan, 2005).

\section{Hubungan Bahan Organik Terhadap Nutrien}

Dari data hasil penelitian yang diperoleh selama penelitian pada kelima lokasi stasiun bahwa kandungan nitrat di muara Sungai Sayung Demak berkisar antara 0,42 - 2,34 mg/L. Secara umum, nilai kandungan nitrat yang diperoleh selama penelitian ini relatif dapat dikatakan nilai yang optimum, cukup baik karena nilai rata - rata nitrat untuk setiap stasiun merupakan faktor pembatas yang baik bagi pertumbuhan biota yang berarti perairan tersebut dengan tingkat kesuburan yang sedang dan masih dalam batasan yang direkomendasikan dalam baku mutu yang ditetapkan oleh KMNLH No. 51 Tahun 2004 yakni 0,008 mg/l. Namun, stasiun I dan II merupakan lokasi yang memiliki nilai kandungan nitrat yang paling tinggi sebesar 2,25 mg/l dan 2,34 mg/l dibanding stasiun yang lain karena letaknya yang berada di tengah muara sungai dan dilakukan pada saat pasang tertinggi yang diduga terjadi pengadukan (turbulensi) dasar peraiaran yang kuat, sehingga nutrien dan bahan organik yang berada di dasar perairan terangkat ke lapisan permukaan, hal tersebut sesuai pendapat Fachrul et al., (2006), distribusi konsentrasi nitrat semakin tinggi menuju ke arah pantai dan konsentrasi tertinggi di temukan di perairan muara sungai. Kandungan nitrat terendah terdapat pada stasiun V (0,42 mg/l) karena letaknya yang sudah berada di laut, semakin mendekati ke arah laut maka konsentrasi nitrat semakin sedikit. Fluktuasi distribusi nitrat selain dipengaruhi buangan limbah dari daratan juga dipengaruhi oleh musim dan angin. Pada musim panas konsentrasi nitrat akan menurun yang diakibatkan dari aktivitas fotosintesa yang tinggi, akan tetapi pada saat yang sama akan terjadi peningkatan kandungan nitrat akibat terjadinya dekomposisi bahan organik. Diantara seluruh stasiun pengamatan, kandungan nitrat terendah terdapat pada stasiun 5 sebesar $0,42-1,2 \mathrm{mg} / \mathrm{l}$. Adanya kandungan nitrat yang rendah dan tinggi dapat disebabkan oleh beberapa faktor, antara lain adanya arus pada kedalaman tersebut yang membawa fosfat dan plankton. Hal tersebut diperkuat oleh hasil analisis statistik dengan uji regresi menggunakan MS.Excel 2003, MS.Excel 2007. Analisis regresi itu sendiri merupakan analisis hubungan keeratan antara bahan organik sebagai peubah tak bebas dengan parameter unsur hara perairan (nitrat). Sudjana (2002) setiap peubah bebas dikatakan mempunyai pengaruh apabila koefisien regresi berbeda nyata pada taraf uji yang ditentukan. Hubungan kandungan bahan organik dengan nitrat mempunyai koefisien korelasi yaitu 0,8209 yang artinya tingginya kandungan bahan organik disertai meningkatnya kandungan nitrat. Hubungan antara bahan organik dengan nitrat secara linier menunjukkan hubungan yang signifikan yaitu y $=0,004 \mathrm{x}-0,8703$ (Gambar 1 ).

Kadar fosfat di muara Sungai Sayung Demak berkisar antara 0,37 - 1,73 mg/L. Nilai kandungan fosfat tertinggi terdapat pada stasiun I $(1,31 \mathrm{mg} / \mathrm{l})$, II $(1,73 \mathrm{mg} / \mathrm{l})$, dan III $(1,59 \mathrm{mg} / \mathrm{l})$ karena berada pada muara sungai yang kaya nutrien dan bahan organik yang berasal dari buangan limbah rumah tangga, aktivitas di daratan yang terbawa oleh arus melalui sungai menuju muara sungai dan berakhir di laut, sedangkan nilai kandungan fosfat terendah terdapat pada stasiun IV $(0,37 \mathrm{mg} / \mathrm{l})$ dan $\mathrm{V}(0,37 \mathrm{mg} / \mathrm{l})$ karena letaknya yang sudah berada di laut, semakin mendekati ke arah laut maka konsentrasi nitrat semakin sedikit. Rendahnya kandungan fosfat pada kedua stasiun ini karena letaknya yang sudah jauh dari daratan dan sudah berada menuju ke laut. Menurut Ibnu (2012) reservoir yang besar dari fosfat berasal dari batu - batuan dan endapan lain yang berada di sekitar perairan tersebut. Fosfat yang berada di bebatuan tersebut akan ditranspor menuju ke tengah laut melalui run off atau saat terjadi hujan seperti pada penelitian yang dilakukan tepat pada saat musim peralihan. Kandungan fosfat umumnya semakin menurun jika semakin jauh ke arah laut, uraian tersebut di atas sesuai dengan pernyataan. Hubungan antara kandungan bahan organik dengan fosfat mempunyai koefisien korelasi yaitu 0,780. Dengan nilai tersebut dapat dikatakan bahwa terdapat hubungan kuat antara kandungan bahan organik dengan fosfat. Hubungan antara bahan organik dengan fosfat secara linier menunjukkan hubungan yang signifikan yaitu $\mathrm{y}=0,0024 \mathrm{x}-0,5213$ (Gambar 2). Meningkatnya kandungan nitrat dan fosfat juga diikuti oleh meningkatnya kelimpahan fitoplankton. Hal ini disebabkan karena fitoplankton membutuhkan nutrien (nitrat dan fosfat) untuk pertumbuhan fitoplankton karena nitrat dan fosfat dikenal sebagai salah satu faktor pembatas dari keberadaan fitoplankton di perairan tersebut.

\section{Pengaruh Distribusi Nutrien Terhadap Klorofil-a}

Sebaran konsentrasi klorofil-a memperlihatkan nilai yang tidak terlalu bervariasi. Pada stasiun 1 mempunyai kisaran klorofil-a antara $1,061-1,353 \mathrm{mg} \mathrm{Chl-a} / \mathrm{m}^{3}$, stasiun 2 sebesar $1,142-1,268 \mathrm{mg}$ Chl$\mathrm{a} / \mathrm{m}^{3}$, stasiun 3 sebesar $1,027-1,351 \mathrm{mg} \mathrm{Chl-a} / \mathrm{m}^{3}$, stasiun 4 sebesar $1,128-1,251 \mathrm{mg} \mathrm{Chl}-\mathrm{a} / \mathrm{m}^{3}$, stasiun 5

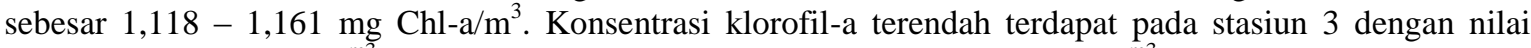
sebesar $1,027 \mathrm{mg} \mathrm{Chl-a} /{ }^{\mathrm{m} 3}$ dan tertinggi pada stasiun 1 sebesar $1,353 \mathrm{mg} \mathrm{Chl-a} /{ }^{\mathrm{m} 3}$. Dilihat dari nilai tersebut dapat dikatakan bahwa kondisi perairan muara Sungai Sayung Demak masih dalam keadaan normal atau tergolong kedalam perairan yang bersifat oligotrofik. Tingginya kandungan klorofil-a di stasiun 1 disebabkan 
oleh adanya suplai nutrien dari daratan yang terbawa oleh aliran sungai menuju ke muara sungai. Riyono (2006) dalam Anindya (2011) memberikan kriteria untuk perairan muara berdasarkan kandungan klorofil-a nya adalah klorofil-a $<15 \mathrm{mg} / \mathrm{m}^{3}$ dikategorikan ke dalam kondisi yang bagus, klorofil-a $15-30 \mathrm{mg} / \mathrm{m}^{3}$ kategori sedang, dan klorofil-a $>30 \mathrm{mg} / \mathrm{m}^{3}$ kategori jelek.

Klorofil-a merupakan pigmen yang paling umum terdapat pada fitoplankton sehingga konsentrasi fitoplankton sering dinyatakan dalam konsentrasi klorofil-a (Parsons et al., 1984). Konsentrasi klorofil-a pada suatu perairan sangat tergantung pada ketersediaan nutrien dan intensitas cahaya matahari. Hasil konsentrasi klorofil-a yang diperoleh dari penelitian ini menunjukkan konsentrasi yang sedang. Menurut Tubalawony (2007), apabila nutrien dan intensitas cahaya matahari cukup tersedia, maka konsentrasi klorofil-a akan tinggi dan sebaliknya. Tingginya kandungan klorofil-a fitoplankton di suatu perairan tidak selalu menggambarkan kondisi yang baik bagi perairan tersebut. Kandungan klorofil-a yang tinggi di suatu perairan mengindikasikan terjadinya eutrofikasi. Pengaruh kelimpahan kandungan nutrien yang tidak terkendali di perairan muara dan laut akan dapat mengganggu ekosistem yang ada di perairan tersebut.

Pola sebaran klorofil-a menunjukkan adanya gradasi nilai konsentrasi klorofil-a yaitu tinggi di muara sungai dan semakin rendah menuju ke arah laut lepas. Konsentrasi yang tinggi juga disebabkan karena pada daerah tersebut terjadi akumulasi nutrien yang berasal dari sungai - sungai yang mengalir menuju muara sungai. Sebaran distribusi klorofil-a fitoplankton dan nutrien menunjukkan nilai yang tinggi hampir selalu ditemukan pada perairan yang dekat dengan pantai seperti muara sungai, sedangkan perairan yang sudah menjauh dari muara sungai kandungannya semakin rendah.

\section{Parameter Fisika-Kimia Perairan}

Hasil pengukuran paramter fisika-kimia tersebut apabila dilihat dari kisaran optimal bagi kehidupan organisme perairan masih berada dalam kisaran yang normal. Hal tersebut sangat berpengaruh terhadap kehidupan fitoplankton maupun biota yang ada di perairan tersebut. Fitoplankton termasuk organisme perairan yang tidak dapat mengatur suhu tubunya. Selama hidupnya suhu tubuh organisme perairan sangat tergantung pada suhu perairan tempat hidupnya. Oleh karena itu adanya perubahan suhu air akan membawa dampak yang cukup berpengaruh bagi fitoplankton. Suhu muara Sungai Sayung Demak berada pada kisaran $30-33^{\circ} \mathrm{C}$. Kisaran suhu tersebut dapat dikatakan bahwa suhu pada lokasi penelitian tersebut masih layak untuk kehidupan organisme di perairan tersebut. Suhu air rata - rata berkisar antara $24-32^{\circ} \mathrm{C}$, kisaran tersebut plankton dapat tumbuh dan berkembang biak (Hutabarat dan Evans, 1984). Dengan demikian, kandungan nitrat dan fosfat akan meningkat jika suhu perairan mendukung pertumbuhan organisme fitoplankton.

Kadar oksigen terlarut (DO) di muara Sungai Sayung Demak berkisar antara 2,7 - 3,4 mg/l. Dilihat dari kisaran nilai tersebut, kondisi perairan muara Sungai Sayung Demak termasuk dalam kriteria kurang layak untuk kehidupan biota perairan. Wardoyo (1982) menyatakan bahwa kehidupan ikan dan kebanyakan organisme perairan lainnya masih dapat hidup dengan layak jika kandungan oksigen terlarut perairan lebih besar dari $3 \mathrm{mg} / \mathrm{l}$. Penyebab utama berkurangnya kadar oksigen terlarut dalam air disebabkan karena adanya zat pencemar yang dapat mengkonsumsi oksigen. Zat pencemar tersebut terutama terdiri dari bahan-bahan organik dan non organik yang berasal dari berbagai sumber, seperti kotoran (hewan dan manusia), sampah organik, bahan-bahan buangan dari industri dan rumah tangga.

Salinitas merupakan salah satu parameter perairan yang berpengaruh pada fitoplankton. Variasi salinitas mempengaruhi laju fotosintesis, terutama di daerah estuari, khususnya pada fitoplankton yang hanya bisa bertahan pada batas-batas salinitas yang kecil. Salinitas yang diperoleh selama penelitian berkisar antara $19-30 \%$, kisaran tersebut masih layak untuk kehidupan organisme perairan yaitu antara $0,5-30 \%$ (Barnes, 1988). Derajat keasaman $(\mathrm{pH})$ yang diperoleh selama penelitian berkisar antara $7-8$. Nilai $\mathrm{pH}$ sangat dipengaruhi oleh aktivitas fotosintesis dan suhu. Kisaran nilai $\mathrm{pH}$ yang diperoleh termasuk dalam kisaran yang ideal untuk kehidupan organisme (fitoplankton) dalam perairan yaitu antara 6,5 - 8,5 (Romimohtarto, 2004). Derajat keasaman $(\mathrm{pH})$ mempunyai pengaruh terhadap kehidupan tumbuhan dan hewan air sehingga sering dipergunakan sebagai petunjuk untuk menyatakan baik buruknya suatu perairan.

Kedalaman pada lokasi penelitian berkisar antara $100-140 \mathrm{~cm}$. Gambaran kualitatif tentang kekeruhan air dapat diketahui dengan pengukuran kecerahan. Kecerahan yang diperoleh selama penelitian berkisar antara $21-56,5$. Kecerahan adalah ukuran transparansi perairan yang diamati secara visual dengan menggunakan secchi disc. Nilai kecerahan dipengaruhi oleh keadaan cuaca, warna perairan, waktu pengukuran, kekeruhan, padatan tersuspensi dan ketelitian orang yang melakukan pengukuran (Effendi, 2003). Kedalaman dan kecerahan perairan akan mempengaruhi penetrasi intensitas cahaya matahari ke dalam perairan. Semakin tinggi kecerahan maka intensitas cahaya matahari yang masuk ke dalam perairan akan semakin besar (Nybakken, 1992). Kecepatan arus yang terjadi dalam lokasi penelitian berkisar antara 0,07$0,16 \mathrm{~m} / \mathrm{det}$. Kecepatan arus tersebut cukup cepat karena dilakukan pada saat pasang air laut. Arus merupakan salah satu faktor yang membatasi penyebaran organisme perairan yaitu seperti plankton yang pergerakan hidupnya mengikuti arus. 


\section{Kesimpulan}

Kesimpulan yang diperoleh dari hasil penelitian adalah sebagai berikut:

1. Fluktuasi dan sebaran bahan organik di perairan muara Sungai Sayung Demak pada kelima staisun lokasi mengalami fluktuasi yang berbeda - beda pada tiap pengulangannya;

2. Distribusi spasial antara kelimpahan fitoplankton, nutrien, dan bahan organik mempunyai pola yang sama; dan

3. Hubungan antara bahan organik dengan nitrat secara linier menunjukkan keeratan yang tinggi dengan nilai koefisien korelasi sebesar 0,8209 . Hubungan antara bahan organik dengan fosfat mempunyai nilai koefisien korelasi sebesar 0,7804. Distribusi nutrien terhadap klorofil-a menunjukkan adanya gradasi nilai konsentrasi klorofil-a yaitu tinggi di muara sungai dan semakin rendah menuju ke arah laut lepas. Berdasarkan nilai rata - rata klorofil-a yang diperoleh sebesar 1,027 - 1,353 $\mu \mathrm{g} / \mathrm{l}$, perairan muara Sungai Sayung Demak tergolong kedalam perairan yang bersifat oligotrofik.

\section{Ucapan Terima Kasih}

Ucapan terima kasih ditujukan kepada Bapak Wawan dan Bapak Saiful yang telah membantu penulis selama kegiatan penelitian di lapangan. Ucapan terima kasih ditujukan pula kepada Dr. Ir. Pujiono Wahyu Purnomo, MS dan Drs. Ign. Boedi Hendrarto, M.Sc,Ph.D atas bimbingannya dalam penyusunan penelitian ini.

\section{Daftar Pustaka}

Anindya, W. 2011. Pola Distribusi Klorofil-a dan Total Suspended Solid (TSS) di Teluk Toli - Toli, Sulawesi. Buletin Oseanografi Marina. FPIK. Universitas Diponegoro.

Barnes, R.S.K dan R.N. Hughes. 1988. An Introduction to Marine Ecology. Second Edition. Blackwell Scientific Publication. London.

Boney, A. D. 1975. Phytoplankton. The Camelot Press. London.

Czernuszenko, W. 1987. Dispersion of Pollutan In Rivers. Hydrological Sciences- Journal-des Sciences Hydrologiques, 32, 1, 3/last. Institute of Metorology and Water Management. Polandia.

DKP. 2004. Pedoman Umum Budidaya Udang Di Tambak. Direktorat Pembudidayaan, Direktorat Jendral Perikanan Budidaya, DKP. Jakarta.

Effendi, M. I. 2003. Biologi Perikanan. Yayasan Pustaka Nusantara.

Fachrul. 2006. Distribusi Spatial dan Ratio N/P di Perairan Teluk Jakarta. Seminar Nasional Penelitian di Perguruan Tinggi IATPI Teknik Lingkungan. ITB. Bandung.

Ghufran, H Kordi K., dan Andi, B, Tancung. 2007. Pengelolaan Kualitas Air Dalam Budidaya Perairan. PT. Rineka Cipta. Jakarta.

Hermawan, W. 1997. Pengantar Metodologi Penelitian Buku Panduan Mahasiswa. PT. Gramedia Pustaka Utama. Jakarta.

Hutabarat, S., dan S. M. Evans. 1984. Pengantar Oseanografi. UI Press. Jakarta.

Ibnu, Z. 2012. Analy's Increases Waters Fertility At Rokan's River Estuary Sighted From Nitrate, Phosphate, And Profusion At Diatom. Jurnal Penelitian Faculty Fisheries and Marine Science. University Riau.

Keputusan Menteri Lingkungan Hidup No. 51 Tahun 2004. Tentang Baku Mutu Air Laut. Kantor Menteri Negara Lingkungan Hidup. Jakarta.

Muller - Wohlfeil, D. I. 2002. Estimating Annual River Discharge and Nitrogen Loading to Danish Coastal Water Based on Multiple Regression, National Environmental Research Institute, Vejlsvej 25. DK8600 Silkborg. Denmark.

Nybakken, J. 1992. Biologi Laut. PT. Gramedia Pustaka Raya. Jakarta.

Parsons, T. R., M. Takeshi and B. Hagrave. 1984. Biological Oceanographic Processes. Third Edition. Oxford. Pergamon Press. Great Britain.

Pirzan, A.M. 2005. Potensi Lahan Budidaya Tambak dan Laut di Kabupaten Minahasa, Sulawesi Utara. Jurnal Penelitian Perikanan Indonesia.

Razak, A. 1991. Statistika bidang pendidikan. Fakultas Keguruan dan Ilmu Pendidikan. Universitas Riau. Pekanbaru.

Riyono, S.H. 2006. Beberapa Metode Pengukuran Klorofil Fitoplankton di Laut. Jurnal Oseana 23(3): 33 44.

Romimohtarto, K. 2004. Meroplankton Laut. Djambatan. Jakarta.

Sudjana. 2002. Metoda Statistika. Tarsito. Bandung.

Tubalawony, S. 2007. Kajian Klorofil-a Dan Nutrien Serta Interelasinya Dengan Dinamika Massa Air di Perairan Barat Sumatera dan Selatan Jawa-Sumbawa. Penelitian. IPB. Bogor.

Wardoyo, S.T.H. 1975. Pengelolaan Kualitas Air (Water Quality Management). Pusat Studi Pengelolaan Sumberdaya Lingkungan. Institut Pertanian Bogor. Bogor.

Wardoyo, S.T.H. 1982. Water Analysis Manual Tropical Aquatic Biology Program Biotrop-Seameo, Bogor, $81 \mathrm{pp}$. 